Article

\title{
Origins and Geochemistry of Dolomites and Their Dissolution in the Middle Triassic Leikoupo Formation, Western Sichuan Basin, China
}

\author{
Shunli Zhang ${ }^{1,2}$, Zhengxiang Lv ${ }^{1,2, *}$, Yi Wen ${ }^{1,2}$ and Sibing Liu ${ }^{1,2}$ \\ 1 State Key Laboratory of Oil-Gas Reservoirs Geology and Exploitation, Chengdu University of Technology, \\ Chengdu 610059, China; zhangshunli91@163.com (S.Z.); denghh994@nenu.edu.cn (Y.W.); \\ sibingliu@163.com (S.L.) \\ 2 College of Energy Resources, Chengdu University of Technology, Chengdu 610059, China \\ * Correspondence: lvzhengxiang13@cdut.cn
}

Received: 18 May 2018; Accepted: 30 June 2018; Published: 6 July 2018

\begin{abstract}
Triassic dolomites occur pervasively in the Western Sichuan Basin. Although these strata have been deeply buried and affected by multiple phases of dolomitization and dissolution, some intervals in the upper part of the Leikoupo Formation have developed high porosity. Based on their petrographic and geochemical features, three major types of dolomite fabrics are recognized, namely, dolomicrite, fabric-retentive dolomite, and fabric-destructive dolomite. Geochemical evidence indicates that the dolomicrite formed following the Sabkha model in a low-temperature hypersaline environment, as these rocks exhibit abnormally high $\mathrm{Sr}$ and Na contents, lower $\mathrm{Fe}$ and $\mathrm{Mn}$ contents, $\delta^{18} \mathrm{O}$ values generally ranging from $-1.70 \%$ to $-1.67 \%$ (with an average value of $-1.69 \%$ ), and higher $\mathrm{Mg} / \mathrm{Ca}$ ratios. The fabric-retentive dolomite formed following the seepage-reflux model in a shallow burial environment, and these rocks exhibit the highest ${ }^{87} \mathrm{Sr} /{ }^{86} \mathrm{Sr}$ ratios, $\delta^{18} \mathrm{O}$ values generally ranging from $-6.10 \%$ to $-2.50 \%$ (with an average value of $-3.98 \%$ ), and a wide range of $\mathrm{Fe}$ and $\mathrm{Mn}$ contents, indicating that they may have been altered by meteoric water. The fabric-destructive dolomite formed following the burial model at elevated temperatures; these rocks exhibit the lowest $\mathrm{Sr}$ and $\mathrm{Na}$ contents, $\delta^{18} \mathrm{O}$ values generally ranging from $-7.01 \%$ to $-6.62 \%$ (with an average value of $-6.79 \%$ ), relatively higher $\mathrm{Mg} / \mathrm{Ca}$ values, and lower ${ }^{87} \mathrm{Sr} /{ }^{86} \mathrm{Sr}$ ratios. The early Sabkha, seepage-reflux dolomitization and penecontemporaneous periodic meteoric freshwater selective dissolution processes formed multi-period, overlapping moldic pores, algal framework pores, and intragranular dissolution pores. The superposition of organic acid dissolution during the burial period is the main controlling factor of the formation of deeply buried, high-quality dolomite reservoirs in the Leikoupo Formation.
\end{abstract}

Keywords: Sichuan basin; Leikoupo Formation; petrographic; geochemistry; dolomitization; dissolution

\section{Introduction}

With the continuous innovation of science and technology, the degree of exploration in oil and gas with middle and shallow layers has been comprehensive. Deep and ultra-deep reservoirs have gradually become important new fields for the development of oil and gas resources, while deep reservoirs often exhibit poor porosity due to having undergone intense compaction and destructive diagenesis. Some carbonate reservoirs that have undergone different stages of dissolution, dolomitization, structural fractures, abnormally high pressures, and early hydrocarbon charging can still maintain good reservoir space even at burial depths of more than $5000 \mathrm{~m}$, such as the Ordovician dolomite reservoirs in the Mills Ranch Field (7663-8103 m), the Madden Formation dolomite reservoirs in the Wind River Basin (7000 m), the Smackover Formation dolomite 
reservoirs in the Black Creeks field ( $\geq 6000 \mathrm{~m})$, the Permian Reef and shoal-facies reservoir in the Sichuan Basin (5027 m-6000 m), and the Ordovician karst fracture reservoir in the Tarim Basin $(6400 \mathrm{~m})$ [1-3]. The research hotspots of carbonates have mainly focused on carbonate deposition patterns, microbial carbonates, and dolomitization methods, as well as their relationships with the sequence stratigraphic framework, sea-level change, and paleoclimate [4-6]. However, few studies have focused on the formation mechanism of deep-buried, high-quality carbonate reservoirs.

The burial depth of the carbonate reservoirs of the Leikoupo Formation in the Western Sichuan Basin is greater than $5500 \mathrm{~m}$, but they maintain relatively good porosity. The mechanism for the formation of deep-buried, high-quality carbonate reservoirs seems to be controlled by various factors. Some authors have emphasized the role of Sabkha dolomitization in the upper tidal zone and the dissolution of aragonite, high-magnesium calcite and gypsum by periodical meteoric freshwater [4,6,7]. It is well known that dolomitization can preserve, reduce, or improve the porosity of carbonate rocks, depending on the type of dolomite, the timing of dolomitization relative to burial, the size of dolomite crystals, and the kind of cement (gypsum, calcite, and quartz), and the percentage of dolomite in carbonate rock [8,9]. However, some authors believe that burial dissolution is the key to high-quality reservoirs, as this process mainly includes the dissolution of organic acids, $\mathrm{CO}_{2}$ dissolution, hydrothermal dissolution, and TSR sulfate thermal reduction [10,11]. However, it remains unclear whether the TSR reaction can improve porosity [12]. Petroleum geologists believe that the pores in carbonate reservoirs are related to the sedimentary environment (which controls the rock composition and structure), diagenesis, burial history, thermal history, and microbial activity $[13,14]$.

\section{Geological Background}

The Sichuan Basin is a large oil-bearing superimposed basin. The study area is located in front of the Longmenshan Orogenic Belt, which represents the boundary between the western edge of the Yangtze plate and the Songpan-Ganzi fold; it is also the eastern boundary of the Tibetan Plateau and the western edge of the Sichuan Basin (Figure 1). Two complete anticline structures have developed in the study area, the Jingma-Yazihe and Shiyangchang anticlines, which are located in the thrust nappe structure between the Anxian-Guanxian fault and the Pengxian fault (Figure 1) [15-17]. There are also some inter-layer small faults that form the network transmission system, especially the Pengxian fault, which not only controls the formation of the Longmenshan Orogenic Belt, but also facilitates the communication of the underlying ultra-deep marine source rock. The Pengxian fault is an important channel for oil and gas migration [16,17].

The study area has mainly experienced two tectonic evolution stages: the Sinian-Middle Triassic passive continental margin tectonic evolution stage, which was characterized by the deposition of thick marine carbonate rocks, and the Late Triassic-Eocene Foreland Basin evolution stage, which was characterized by the deposition of thick terrestrial clastic rocks [17,18]. During the Triassic, the development of the Feixianguan Formation, Jialinjiang Formation, Leikoupo Formation, Xujiahe Formation, and Leikoupo Formation represented the final evolutionary stage of marine carbonates in the Sichuan Basin. The sedimentary facies of the basin are characterized by restricted to evaporitic platform facies. The rocks of the Leikoupo Formation are characterized by multiple cycles of marine carbonates and evaporites, including limestones, dolomites, gypsum, and salt rocks; the thicknesses of these deposits range from $200 \mathrm{~m}$ to $1000 \mathrm{~m}$ (Figure 1) [16-20]. During the Indosinian period, the paleo-Tethys was subducted beneath the western margin of the Yangtze craton, causing the Leikoupo Formation to be unconformably overlain by the Upper Triassic Xujiahe Formation. The Leikoupo Formation can be divided into four members based on lithology; its high-quality reservoirs are mainly located in the Lei 4 Member [18-20]. 


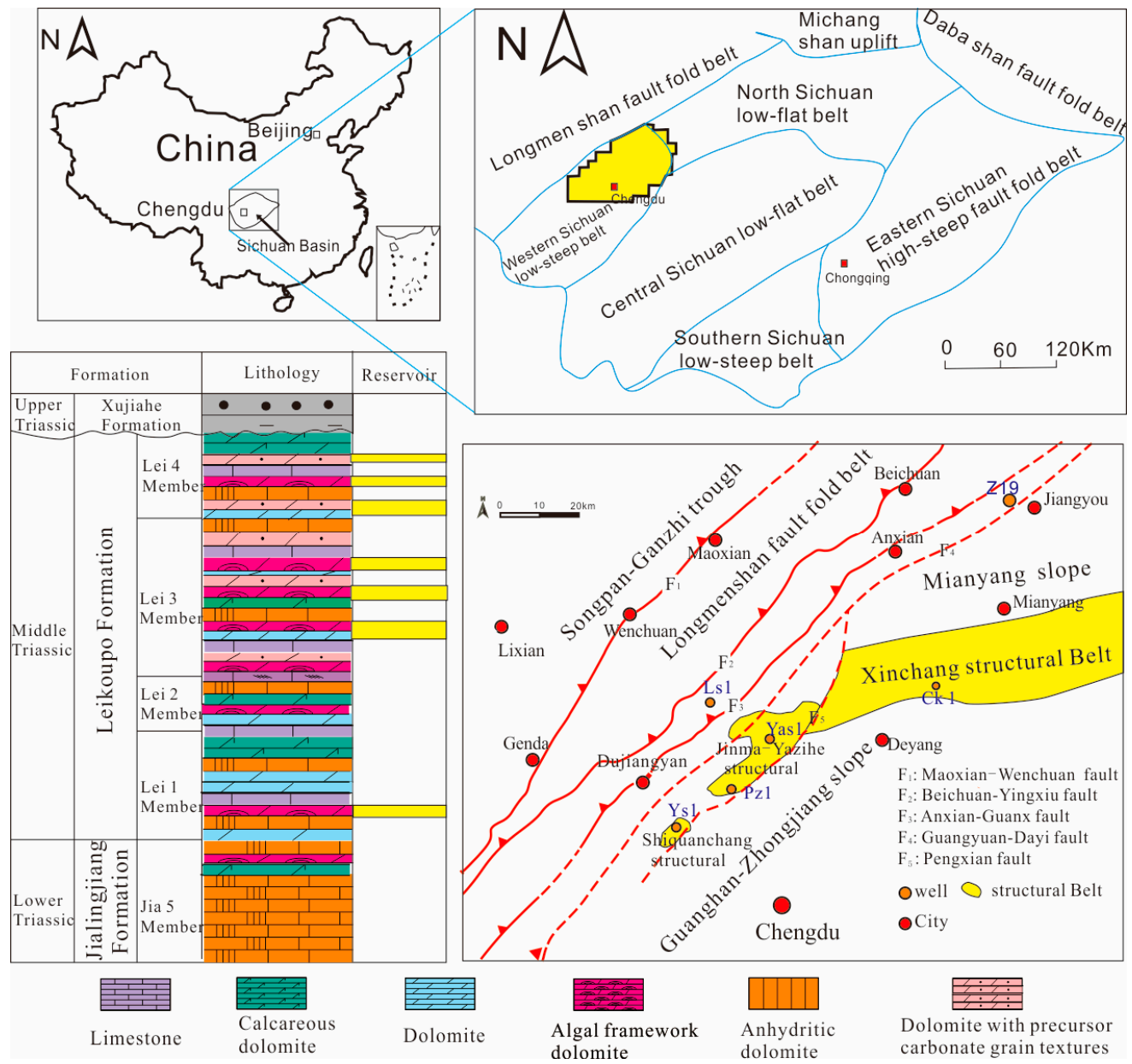

Figure 1. The location and tectonic characteristics of the study area, and the Middle Triassic stratigraphic column for the Western Sichuan Basin.

\section{Materials and Methods}

A total of 102 samples were collected from the three wells of the Triassic Leikoupo Formation, in the western region of the Sichuan Basin, with burial depths ranging from $5500 \mathrm{~m}$ to $6500 \mathrm{~m}$. A total of 86 samples were selected for thin section observation. The sections were prepared for multi-purpose analysis with blue-dyed epoxy impregnation and double-sided polishing. Geochemical and sedimentary environmental information were obtained using cathodoluminescence images obtained using a CL8200 MK5 system with an acceleration voltage of $30 \mathrm{kV}$, a beam current of $2 \mathrm{nA}$ and a working distance of $5 \mathrm{~mm}$.

In situ carbon and oxygen isotope analyses were performed using a Nd:YAG laser microprobe in the Geological Laboratory of Research Institute of Exploration and Development, Southwest Oil and Gas Field Company, Chengdu, China. The laser probe micro-sampling of $C$ and $O$ from dolomite for isotopic analysis was achieved by focusing a laser beam with a wavelength of $1064 \mathrm{~nm}$ and a diameter of $20 \mu \mathrm{m}$ onto a sample situated in a vacuum chamber to ablate a small area on the sample and liberate $\mathrm{CO}_{2}$ gas. After purification, the $\mathrm{CO}_{2}$ gas was led directly into a Finnigan MAT 252 mass spectrometer (Thermo Electron Corporation, Waltham, MA, USA) for isotopic analysis. The carbon and oxygen isotopic compositions herein were recorded using conventional $\delta^{13} \mathrm{C}$ and $\delta^{18} \mathrm{O}$ notations with respect to the Vienna Peedee belemnite (VPDB) standard, respectively. The precision and reproducibility of both isotopic analyses are at least $\pm 0.2 \%$. 
${ }^{87} \mathrm{Sr} /{ }^{86} \mathrm{Sr}$ ratios were measured on a MAT262 solid isotope mass spectrometer (Thermo Electron Corporation, Waltham, MA, USA) in the State Key Laboratory of Oil and Gas Reservoir Geology and Exploitation. Carbonate samples (70 mg passed through a 200-mesh sieve) were dissolved for $2 \mathrm{~h}$ in $0.8 \mathrm{~mol} / \mathrm{L}$ hydrochloric acid in a Teflon vessel prior to the analysis of their strontium isotope ratios. Pure strontium for isotopic analysis was separated from the centrifuged dissolved samples using an AG50W $\times 8\left(\mathrm{H}^{+}\right)$cation exchange column and hydrochloric acid leaching. The blank values for all steps are approximately from $2 \times 10^{-10}$ to $5 \times 10^{-10} \mathrm{~g}$. The error is expressed by $2 \sigma( \pm)$.

Major/trace elements analysis were measured on an inductively coupled plasma optical emission spectrometer (ICP-OES) housed at the Key Laboratory of Petroleum Resources Research, Institute of Geology and Geophysics, Chinese Academy of Sciences, Lanzhou, China. The instrument model was Elan DRC-e (PerkinElmer corporation, Waltham, MA, USA). The detection limit was from 0.01 to $0.2 \mu \mathrm{g} / \mathrm{g}$. The analysis error is less than $3 \%$.

\section{Results}

\subsection{Petrography}

The lithologies in the study area of the Leikoupo Formation comprise dolomite and limestone carbonate, as well as evaporites. Based on petrographic observations, the major diagenetic processes that have affected this rock unit include microbial micritization, calcite cementation, mechanical and chemical compaction, neomorphism, dolomitization, and anhydritization. Three dolomite types can be distinguished in the Leikoupo Formation carbonates: (1) dolomicrite; (2) fabric-retentive dolomite; and (3) fabric-destructive dolomite.

\subsubsection{Dolomicrite}

This type of dolomite is microcrystalline to finely crystalline and comprises subhedral to anhedral crystals (Figure 2a). These dolomites are mostly dense and lack algal layers and bioclastic dolomite. This type of dolomite primarily forms in low-energy sedimentary environments and is partially to completely dolomitized. Fine-scale depositional structures (i.e., laminations, birds-eye structures and bioturbation structures) are well-preserved. This type of dolomite is associated with anhydrite nodules and calcite cementation.

\subsubsection{Fabric-Retentive Dolomite}

These dolomites are euhedral to semi-euhedral crystalline rocks. The original sedimentary structures (i.e., laminations and birds-eye structures) are well-preserved and mainly include algal framework dolomite (Figure 2b) and dolomite with precursor carbonate grain textures (Figure 2c). These dolomites are produced in high-energy environments and are partially to completely dolomitized. The boundaries of the grain textures and algae skeletons are clear. The intergranular pores are dominantly filled with dolomite cement, and anhydrite and calcite cements are occasionally visible. The occurrence of slightly compacted contacts between dolomitized grains suggests that dolomitization took place before significant burial occurred. The dissolution of gypsum or calcite can be seen under the microscope.

\subsubsection{Fabric-Destructive Dolomite}

These dolomites are finely crystalline; such dolomites are commonly present as euhedral crystals that may almost completely obliterate the pre-existing limestone textures (Figure 2d). Intercrystalline pores and intercrystalline dissolution pores are developed. These dolomite crystals show cloudy (inclusion-rich) cores and relatively clear outer rims. The identification of original depositional features and facies is difficult. 

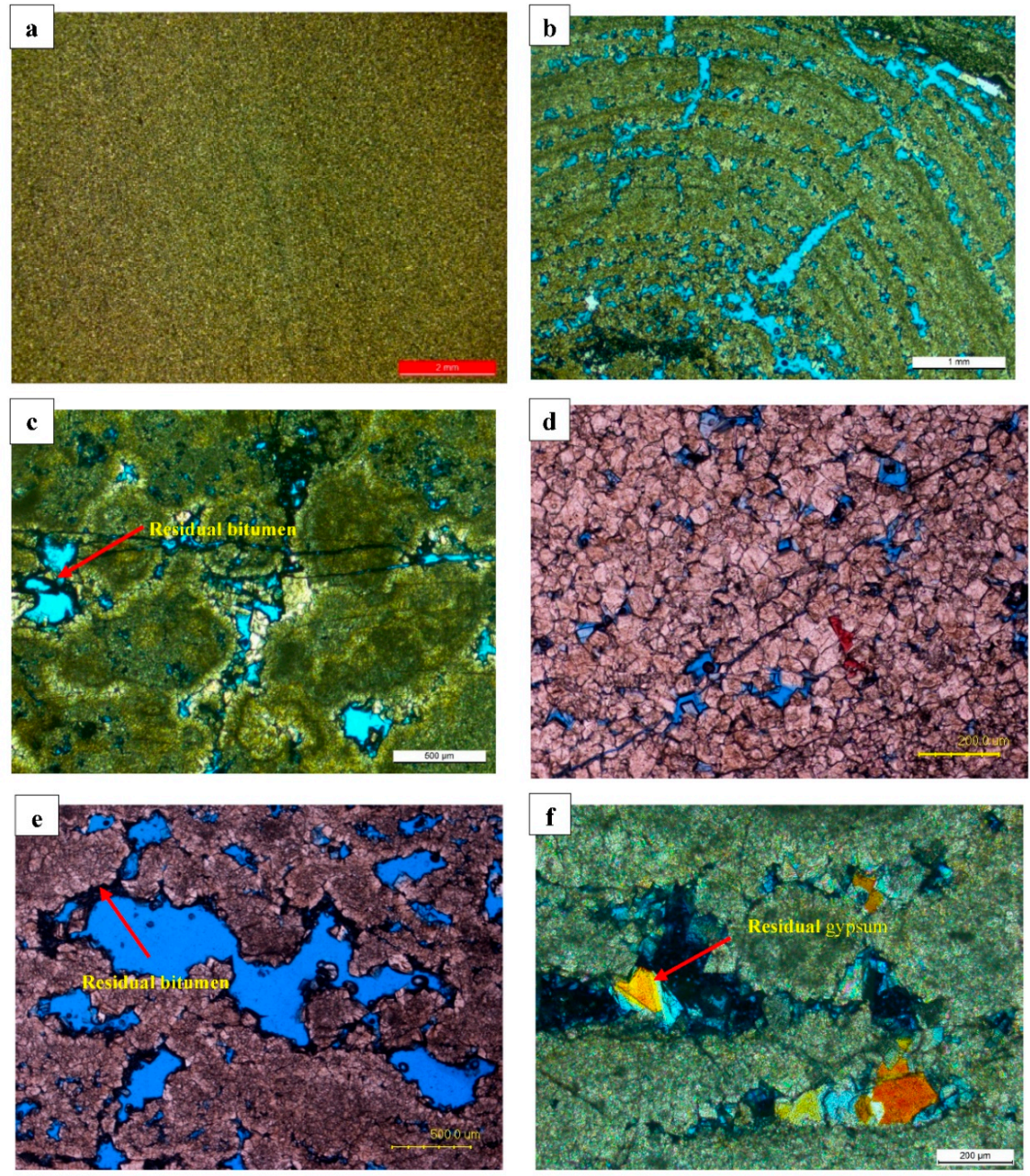

Figure 2. Photomicrographs of the Leikoupo Formation dolomites. (a) Well Yas1, $5774.42 \mathrm{~m}$, dolomicrite; (b) Well Ys1, 6200.39 m, algal framework dolomite, algal framework pores; (c) Well Ys1, $6223.63 \mathrm{~m}$, dolomite with precursor carbonate grain textures, intergranular dissolution pores; (d) Well Ys1, $6197.21 \mathrm{~m}$, fabric-destructive dolomite, intercrystalline pores; (e) Well Ys1, $6219.66 \mathrm{~m}$, moldic pores, residual bitumen; and (f) Well Ys1, 6215.38 m, residual gypsum, moldic pores, intergranular dissolution pores.

\subsection{Pore Types}

Two pore types can be distinguished in the Leikoupo Formation carbonates: (1) dissolution pores, such as algal framework pores (Figure 2b), moldic pores (Figure 2e), and intergranular dissolution pores (Figure 2e,f), which mainly include the selective dissolution of early gypsum, calcite and aragonitic minerals. (2) Intercrystalline pores (Figure 2d), which mainly occur in the fine crystalline dolomites formed by dolomitization. The most important pore types are the algal framework pores, intergranular dissolved pores, and moldic pores, which account for $70 \%$ of all pores. These pores vary in shape and are mainly developed in the fabric-retentive algal framework dolomite.

\subsection{Cathodoluminescence (CL) Analysis}

Luminescence in carbonates is mostly controlled by the relative abundances of $\mathrm{Mn}^{2+}$ and $\mathrm{Fe}^{2+}$ in the crystal lattice [21]. $\mathrm{Mn}^{2+}$ is considered to be an activator and $\mathrm{Fe}^{2+}$ is considered to be a quencher, meaning that higher amounts of $\mathrm{Mn}^{2+}$ lead to bright luminescence and high amounts of $\mathrm{Fe}^{2+}$ cause dull luminescence or non-luminescence [22]. Most dolomites in the Leikoupo Formation exhibit dull 
luminescence or non-luminescence, which is related to their lower Mn contents. The fabric-retentive algal framework dolomite and dolomite with precursor carbonate grain textures display bright red luminescence (Figure 3c-f). The fabric-destructive dolomite that has undergone strong diagenesis shows moderately bright luminescence, while the dolomicrite shows dull luminescence (Figure 3a,b).
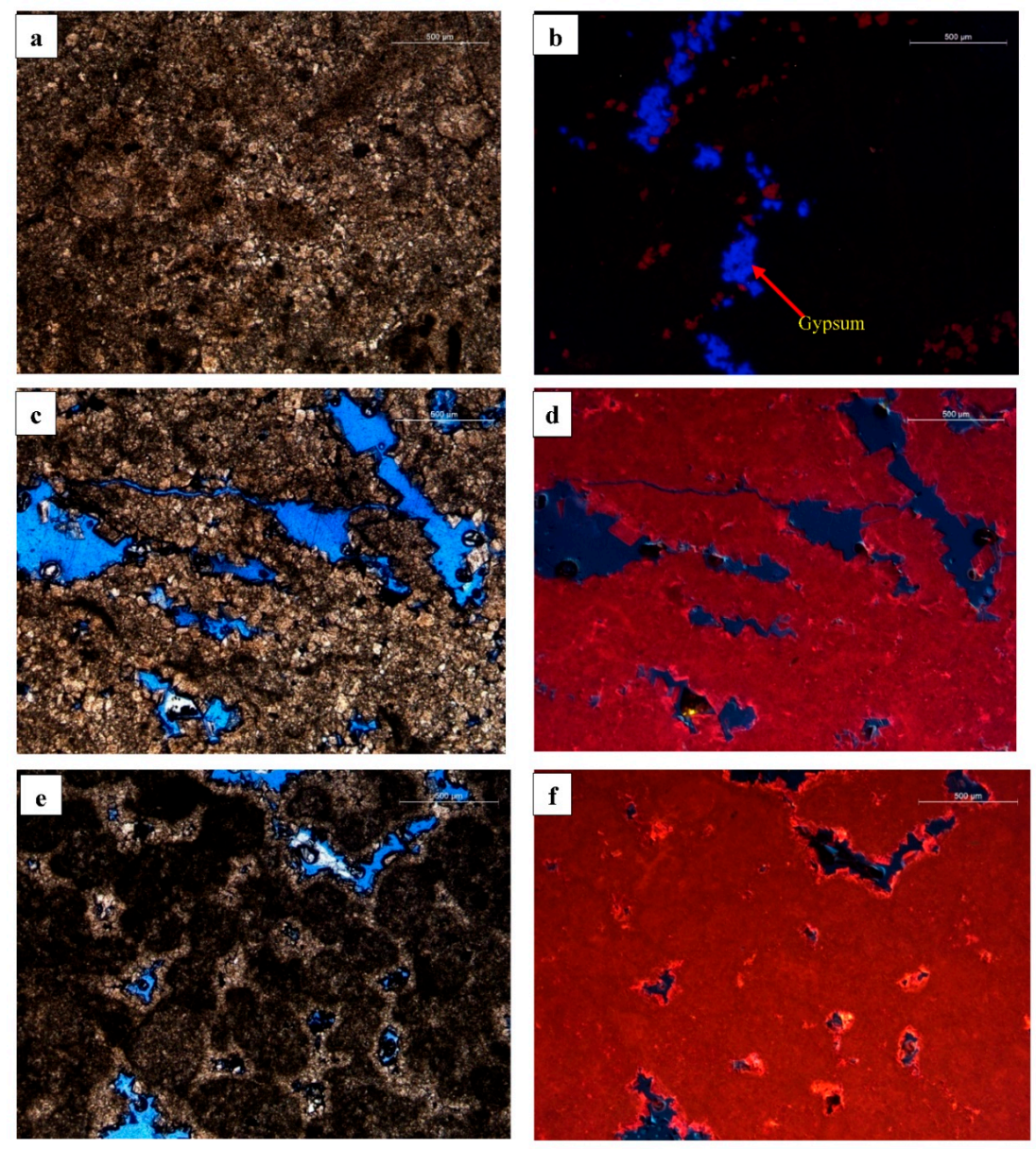

Figure 3. Cathodoluminescence micrograph of the Leikoupo Formation dolomites. (a,b) Well Yas1, $5738.8 \mathrm{~m}$, dolomicrite, dull luminescence; (c,d) Well Ys1, $6196.27 \mathrm{~m}$, algal framework dolomite, bright red luminescence; and (e,f) Well Ys1, $6223.63 \mathrm{~m}$, dolomite with precursor carbonate grain textures, bright red luminescence.

\subsection{Geochemistry}

\subsection{1. $\delta^{13} \mathrm{C}$ and $\delta^{18} \mathrm{O}$ Isotopes}

The $\delta^{13} \mathrm{C}$ and $\delta^{18} \mathrm{O}$ isotopic compositions of 19 carbonate samples (dolomicrite, fabric-retentive dolomite, fabric-destructive dolomite and calcite) are presented here (Figure 4, Table 1 ). The $\delta^{18} \mathrm{O}$ values of the dolomite range from $-7.01 \%$ to $-1.67 \%$ (with an average value of $-4.34 \%$ ). The distribution characteristics of the $\delta^{18} \mathrm{O}$ values in different types of rocks indicate that the $\delta^{18} \mathrm{O}$ values in the dolomicrite, fabric-retentive dolomite, fabric-destructive dolomite, and pore-filling calcite gradually become more depleted. The $\delta^{18} \mathrm{O}$ values in the dolomicrite range from $-1.70 \%$ to $-1.67 \%$ (with an average value of $-1.69 \%$ ), those of the fabric-retentive dolomite range from $-6.10 \%$ to $-2.50 \%$ (with an average value of $-4.14 \%$ ), and those of the fabric-destructive dolomite range from $-7.01 \%$ to $-6.62 \%$ (with an average value of $-6.79 \%$ ). The $\delta^{18} \mathrm{O}$ values of the pore-filling calcite are more depleted, as they range from $-8.54 \%$ to $-7.25 \%$ (with an average value of $-7.96 \%$ ). 
The carbon isotopic compositions of carbonates are indicators of the carbon sources incorporated during carbonate formation. The $\delta^{13} \mathrm{C}$ values of dolomites are mainly dependent on the relative amount of $\mathrm{CO}_{2}$ supplied from pore water carbonate ions, the dissolution of biogenic carbonate precursors, and the degradation of organic matter [23]. The $\delta^{13} \mathrm{C}$ values of the dolomites and pore-filling calcite range from $1.95 \%$ to $6.1 \%$ and $0.31 \%$ to $2.13 \%$, respectively.

The salinity index $Z$ and paleo temperature $T$ are two indicators that can be used to determine the salinity and temperature of dolomitization using $\mathrm{C}-\mathrm{O}$ isotopes [24]. These two indicators are calculated as follows: $Z=2.048\left(\delta^{13} \mathrm{C}_{\mathrm{d}}+50\right)+0.498\left(\delta^{18} \mathrm{O}_{\mathrm{d}}+50\right)[25,26]$ and $T=31.9-5.55\left(\delta^{18} \mathrm{O}_{\mathrm{d}}-\delta^{18} \mathrm{O}_{\mathrm{w}}\right)+$ $0.17\left(\delta^{18} \mathrm{O}_{\mathrm{d}}-\delta^{18} \mathrm{O}_{\mathrm{w}}\right)^{2}[27,28]$, where $\delta^{13} \mathrm{C}_{\mathrm{d}}, \delta^{18} \mathrm{O}_{\mathrm{d}}$ and $\delta^{18} \mathrm{O}_{\mathrm{w}}$ are the isotopic compositions of dolomite (VPDB) and seawater (SMOW). The results show that most dolomite samples have $Z$ values of $>130$ (Table 1), which indicates that these dolomites were formed in a high-salinity saltwater environment. The dolomicrite could have formed at temperatures between 40 and $45^{\circ} \mathrm{C}$, whereas the fabric-retentive dolomites, fabric-destructive dolomites and pore-filling calcite could have formed between 50 and $75^{\circ} \mathrm{C}, 75$ and $80{ }^{\circ} \mathrm{C}$, and 85 and $95^{\circ} \mathrm{C}$, respectively (Table 1). Thus, the results of oxygen isotope thermometry indicate that the fabric-destructive dolomites and pore-filling calcite formed at relatively higher temperatures.

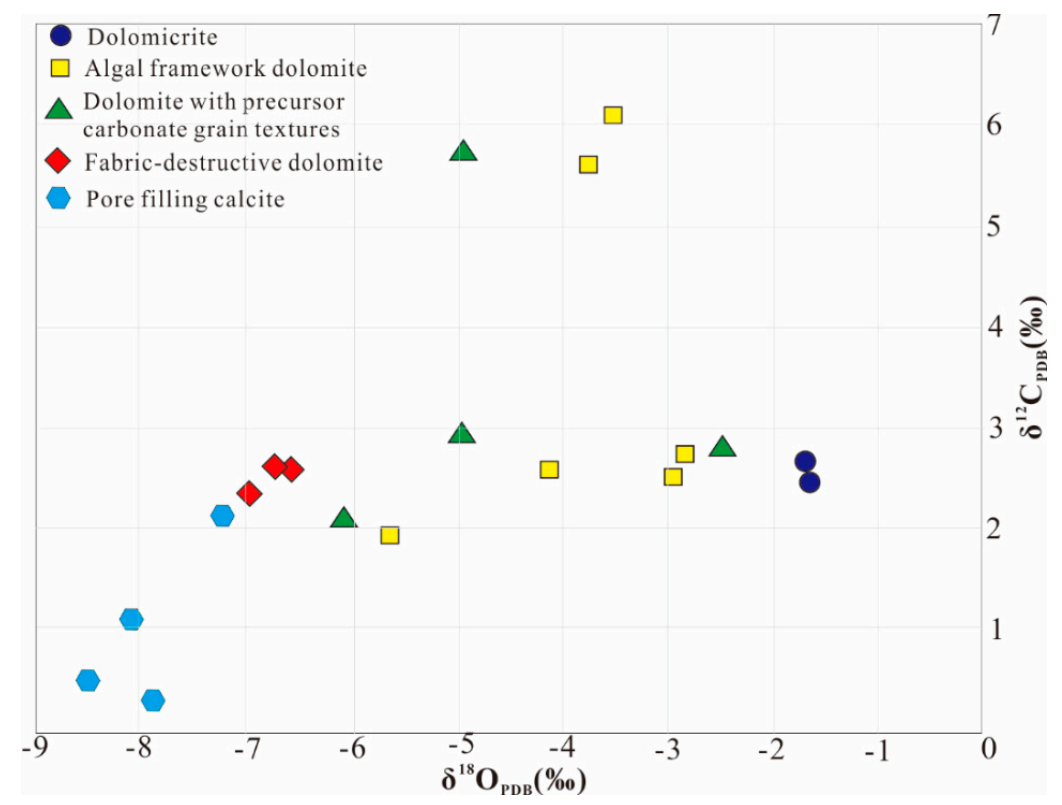

Figure 4. Plot of $\delta^{13} \mathrm{C}$ and $\delta^{18} \mathrm{O}$ values of the dolomicrite, fabric-retentive dolomite, fabric-destructive dolomite, and calcite of the Leikoupo Formation, Western Sichuan Basin.

\subsubsection{Strontium Isotopes}

The Sr isotope compositions of these samples are shown in Figure 5 and Table 1. The ${ }^{87} \mathrm{Sr} /{ }^{86} \mathrm{Sr}$ ratios of the Leikoupo Formation vary from 0.707669 to 0.708605 . The dolomicrite has the lowest ${ }^{87} \mathrm{Sr} /{ }^{86} \mathrm{Sr}$ ratios, which range from 0.707680 to 0.707778 (with an average value of 0.707729 ). The ${ }^{87} \mathrm{Sr} /{ }^{86} \mathrm{Sr}$ ratios of the fabric-retentive algal framework dolomite and dolomite with precursor carbonate grain textures have similar values of 0.707694 to 0.708103 (with an average value of 0.708071 ) and 0.707969 to 0.708246 (with an average value of 0.708065 ), respectively. The ${ }^{87} \mathrm{Sr} /{ }^{86} \mathrm{Sr}$ ratios of the fabric-destructive dolomite range from 0.707669 to 0.708103 (with an average value of 0.707956), indicating that the fabric-destructive dolomites have lighter oxygen isotope values and strontium isotopic ratios compared to the fabric-retentive dolomite. 
Table 1. Stable isotope compositions, major and trace elemental concentrations of dolomite samples in the Leikoupo Formation, Western Sichuan Basin.

\begin{tabular}{|c|c|c|c|c|c|c|c|c|c|c|c|c|c|c|}
\hline \multirow{2}{*}{ Well } & \multirow{2}{*}{$\begin{array}{l}\text { Depth } \\
\text { (m) }\end{array}$} & \multirow{2}{*}{ Lithology } & \multirow{2}{*}{$\mathrm{MgO} \%$} & \multirow{2}{*}{$\mathrm{CaO} \%$} & \multirow{2}{*}{$\begin{array}{c}\mathrm{Sr} \\
(\mu \mathrm{g} / \mathrm{g})\end{array}$} & \multirow{2}{*}{$\begin{array}{c}\mathrm{Na} \\
(\mu \mathrm{g} / \mathrm{g})\end{array}$} & \multirow{2}{*}{$\underset{(\mu \mathrm{g} / \mathrm{g})}{\mathrm{Fe}}$} & \multirow{2}{*}{$\underset{(\mu \mathrm{g} / g)}{\mathrm{Mn}}$} & \multirow{2}{*}{$\begin{array}{l}\delta^{13} \mathrm{C} \\
\text { PDB }\end{array}$} & \multirow{2}{*}{$\begin{array}{l}\delta^{18} \mathrm{O} \\
\mathrm{PDB}\end{array}$} & \multicolumn{2}{|c|}{ Sr isotope Ratio } & \multirow{2}{*}{$\begin{array}{l}\text { Salinity } \\
\text { Index } Z\end{array}$} & \multirow{2}{*}{$\begin{array}{c}\text { Paleo } \\
\text { Temperature }\left({ }^{\circ} \mathrm{C}\right)\end{array}$} \\
\hline & & & & & & & & & & & ${ }^{87} \mathrm{Sr} /{ }^{86} \mathrm{Sr}$ & $2 \sigma( \pm)$ & & \\
\hline Ys1 & 6238.9 & Dolomicrite & 19.7 & 29.1 & 3968.9 & 1060.0 & 190.0 & 11.9 & 2.64 & -1.70 & 0.707680 & 0.000010 & 131.9 & 41.8 \\
\hline Ys1 & 6243.4 & Dolomicrite & 19.0 & 29.2 & 1122.0 & 900.0 & 100.0 & 10.5 & 2.48 & -1.67 & 0.707778 & 0.000014 & 131.5 & 41.6 \\
\hline Yas1 & 5779.4 & Algal framework dolomite & 21.8 & 30.8 & 108.7 & 900.0 & 560.0 & 28.6 & 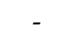 & - & 0.708605 & 0.000011 & - & - \\
\hline Yas1 & 6220.0 & Algal framework dolomite & 20.4 & 29.9 & 107.7 & 870.0 & 170.0 & 24.3 & 2.52 & -2.96 & 0.708104 & 0.000013 & 131.0 & 49.8 \\
\hline Yas1 & 5793.9 & Algal framework dolomite & 21.4 & 30.4 & 106.6 & 900.0 & 300.0 & 25.7 & 5.62 & -3.77 & 0.708067 & 0.000010 & 136.9 & 55.2 \\
\hline Ys1 & 6213.8 & Algal framework dolomite & 21.4 & 30.1 & 87.3 & 1050.0 & 170.0 & 21.5 & 2.77 & -2.85 & 0.707998 & 0.000012 & 131.6 & 49.1 \\
\hline Yas1 & 5775.8 & Algal framework dolomite & 20.7 & 30.1 & 83.3 & 840.0 & 130.0 & 25.0 & 2.58 & -4.13 & 0.708094 & 0.000012 & 130.5 & 57.7 \\
\hline Yas1 & 5787.8 & Algal framework dolomite & 21.2 & 29.4 & 95.5 & 870.0 & 310.0 & 25.9 & 1.95 & -5.64 & 0.708053 & 0.000013 & 128.5 & 68.6 \\
\hline Ys1 & 6196.3 & Algal framework dolomite & 21.0 & 31.1 & 107.3 & 790.0 & 120.0 & 23.0 & 6.10 & -3.55 & 0.708033 & 0.000014 & 138.0 & 53.7 \\
\hline Yas1 & 5759.0 & Algal framework dolomite & 19.6 & 29.5 & 92.5 & 850.0 & 480.0 & 25.9 & - & - & 0.707694 & 0.000010 & - & - \\
\hline Yas1 & 5770.5 & Algal framework dolomite & 23.0 & 32.4 & 126.2 & 810.0 & 540.0 & 23.6 & - & - & 0.708154 & 0.000011 & - & - \\
\hline Ys1 & 6197.9 & Algal framework dolomite & 21.9 & 30.9 & 91.7 & 910.0 & 100.0 & 20.9 & - & - & 0.707912 & 0.000011 & - & - \\
\hline Ys1 & 6205.7 & Dolomite with precursor carbonate grain textures & 21.1 & 29.9 & 103.1 & 930.0 & 80.0 & 27.2 & 2.14 & -6.10 & 0.707969 & 0.000012 & 128.6 & 72.1 \\
\hline Yas1 & 5762.4 & Dolomite with precursor carbonate grain textures & 21.3 & 30.9 & 91.1 & 830.0 & 160.0 & 25.6 & 2.97 & -4.97 & 0.707994 & 0.000010 & 130.9 & 63.7 \\
\hline Yas1 & 5791.7 & Dolomite with precursor carbonate grain textures & 21.9 & 31.8 & 97.8 & 880.0 & 230.0 & 25.0 & 5.73 & -4.95 & 0.708246 & 0.000011 & 136.6 & 63.5 \\
\hline Ys1 & 6216.2 & Dolomite with precursor carbonate grain textures & 20.6 & 28.3 & 119.1 & 810.0 & 220.0 & 26.9 & 2.83 & -2.50 & 0.708050 & 0.000012 & 131.9 & 46.8 \\
\hline Yas1 & 5788.8 & Fabric-destructive dolomite & 22.7 & 30.4 & 65.2 & 800.0 & 280.0 & 25.2 & - & - & 0.708049 & 0.000013 & - & - \\
\hline Yas1 & 5722.1 & Fabric-destructive dolomite & 22.1 & 30.9 & 74.2 & 800.0 & 170.0 & 31.7 & - & - & 0.708103 & 0.000012 & - & - \\
\hline Yas1 & 5774.4 & Fabric-destructive dolomite & 21.1 & 30.3 & 65.4 & 770.0 & 300.0 & 29.8 & 2.36 & -7.01 & 0.707909 & 0.000009 & 128.6 & 79.2 \\
\hline Yas1 & 5781.0 & Fabric-destructive dolomite & 21.6 & 30.9 & 91.5 & 780.0 & 410.0 & 27.3 & 2.60 & -6.62 & 0.707965 & 0.000013 & 129.3 & 76.1 \\
\hline Ys1 & 6183.9 & Fabric-destructive dolomite & 21.1 & 32.3 & 78.8 & 810.0 & 230.0 & 25.4 & - & - & 0.708039 & 0.000011 & - & - \\
\hline Yas1 & 5782.3 & Fabric-destructive dolomite & 21.2 & 29.5 & 59.6 & 840.0 & 280.0 & 25.3 & 2.63 & -6.75 & 0.707669 & 0.000012 & 129.3 & 77.1 \\
\hline Ys1 & 5735.0 & Pore-filling calcite & - & - & - & - & - & - & 0.50 & -8.54 & - & & - & 91.7 \\
\hline Ys1 & 5735.0 & Pore-filling calcite & - & - & - & - & - & - & 0.31 & -7.92 & - & & - & 86.5 \\
\hline Ys1 & 5769.7 & Pore-filling calcite & - & - & - & - & - & - & 1.11 & -8.11 & - & & - & 88.1 \\
\hline Ys1 & 6199.8 & Pore-filling calcite & - & - & - & - & - & - & 2.13 & -7.25 & - & & - & 81.1 \\
\hline
\end{tabular}

Note: $Z=2.048\left(\delta^{13} \mathrm{C}_{\mathrm{d}}+50\right)+0.498\left(\delta^{18} \mathrm{O}_{\mathrm{d}}+50\right), T\left({ }^{\circ} \mathrm{C}\right)=31.9-5.55\left(\delta^{18} \mathrm{O}_{\mathrm{d}}-\delta^{18} \mathrm{O}_{\mathrm{w}}\right)+0.17\left(\delta^{18} \mathrm{O}_{\mathrm{d}}-\delta^{18} \mathrm{O}_{\mathrm{w}}\right)^{2}$. 


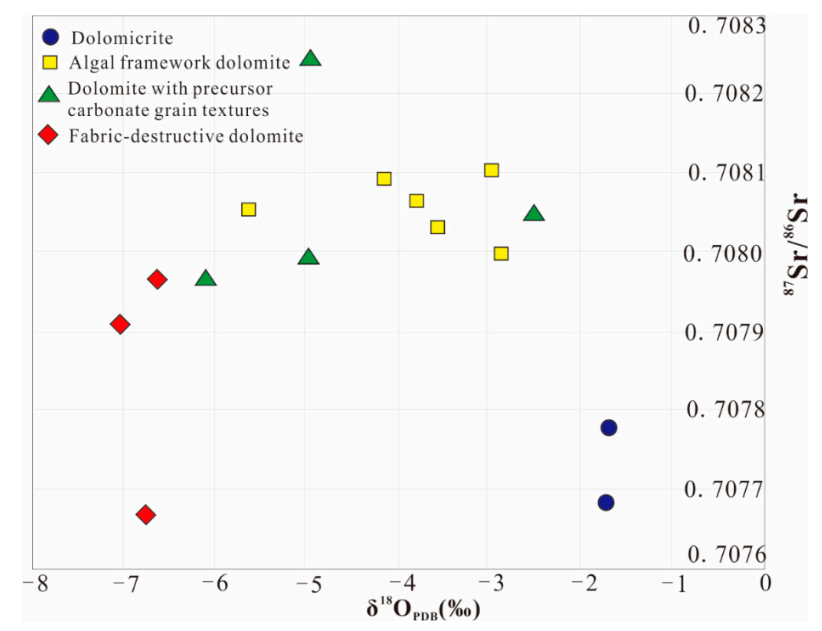

Figure 5. Plot of ${ }^{87} \mathrm{Sr} /{ }^{86} \mathrm{Sr}$ ratios and $\delta^{18} \mathrm{O}$ values of the dolomicrite, fabric-retentive dolomite, and fabric-destructive dolomite of the Leikoupo Formation, Western Sichuan Basin.

\subsubsection{Major Elements}

\section{Calcium and Magnesium}

The dolomites of the Leikoupo Formation show a wide range of $\mathrm{CaO}$ and $\mathrm{MgO}$ values, which range from $28.3 \%$ to $32.4 \%$ (with an average value of $30.4 \%$ ) and $19.0 \%$ to $23.0 \%$ (with an average value of $21.2 \%$ ), respectively (Figure 6a, Table 1). Both of these ranges are lower than the theoretical values of $\mathrm{CaO}(30.41 \%)$ and $\mathrm{MgO}(21.86 \%)$ in stoichiometric dolomite. The fabric-destructive dolomite has lower $\mathrm{Mg} / \mathrm{Ca}$ ratios and exhibits a negative correlation between $\mathrm{MgO}$ and $\mathrm{CaO}$, which indicates that the recrystallization of dolomite occurred after the burial stages. The dolomicrite has higher $\mathrm{Mg} / \mathrm{Ca}$ ratios, with a positive correlation that reflects the rapid crystallization of dolomite in a penecontemporaneous evaporation background [29,30].
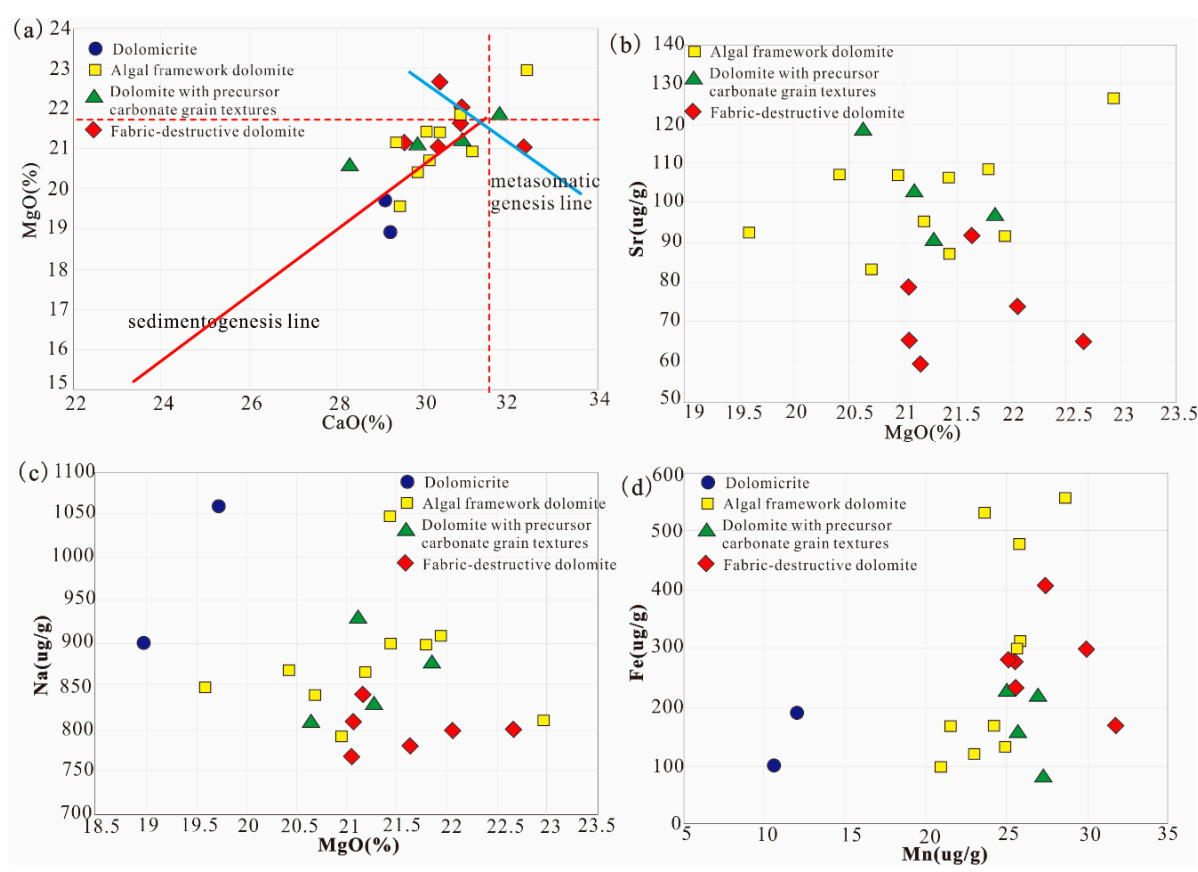

Figure 6. Cross plot of $\mathrm{MgO} / \mathrm{CaO}(\mathbf{a}), \mathrm{Sr} / \mathrm{MgO}(\mathbf{b}), \mathrm{Na} / \mathrm{MgO}$ (c), and $\mathrm{Fe} / \mathrm{Me}$ (d) for Leikoupo Formation dolomite, Western Sichuan Basin. 


\subsubsection{Trace Elements}

Strontium

$\mathrm{Sr}$ is one of the most important trace elements associated with dolomite. The concentration of $\mathrm{Sr}$ depends on the crystalline habit of dolomite, the properties of the diagenetic fluid (such as salinity) and the precursors of dolomite, which include many factors [6,31]. Primary dolomites contain higher Sr contents than secondary (diagenetic) dolomites [32]. The dolomicrite records the highest $\mathrm{Sr}$ contents, ranging from $1122 \mu \mathrm{g} / \mathrm{g}$ to $3968.9 \mu \mathrm{g} / \mathrm{g}$ (with an average value of $2545.5 \mu \mathrm{g} / \mathrm{g}$ ), which are higher than those of the dolomites that precipitated from normal seawater, i.e., $470-570 \mu \mathrm{g} / \mathrm{g}[33,34]$. The fabric-retentive dolomite record a wide range of $\mathrm{Sr}$ contents ranging from $83.3 \mu \mathrm{g} / \mathrm{g}$ to $126.2 \mu \mathrm{g} / \mathrm{g}$ (with an average value of $101.3 \mu \mathrm{g} / \mathrm{g}$ ), which indicates that their associated dolomitization was affected by multiple factors. The fabric-destructive dolomite has the lowest $\mathrm{Sr}$ content, ranging from $59.6 \mu \mathrm{g} / \mathrm{g}$ to $91.5 \mu \mathrm{g} / \mathrm{g}$ (with an average value of $72.5 \mu \mathrm{g} / \mathrm{g}$ ), possibly reflecting recrystallization during late burial diagenesis (Figure 6b, Table 1) [35].

\section{Sodium}

Sodium is the most abundant cation in seawater, and it has been recognized as a paleosalinity indicator in ancient fluids [36]. The dolomicrite has the highest Na content (with an average value of $980 \mu \mathrm{g} / \mathrm{g}$ ) compared to the other types of dolomites, which indicates that this dolomite was related to the dolomitization of high-salinity pore-water fluids in the penecontemporaneous stage. The $\mathrm{Na}$ contents vary relatively widely in the fabric-retentive algal framework dolomite (with an average value of $863.0 \mu \mathrm{g} / \mathrm{g}$ ) and dolomite with precursor carbonate grain textures (with an average value of $879 \mu \mathrm{g} / \mathrm{g}$ ), and the fabric-destructive dolomite has the lowest Na content (with an average value of $800 \mu \mathrm{g} / \mathrm{g}$ ) (Figure 6c, Table 1). These data reflect obvious differences in the diagenetic fluid involved in the dolomitization process.

\section{Iron and Manganese}

Since the contents of $\mathrm{Fe}$ and $\mathrm{Mn}$ in seawater are much lower than those in formation water, a reducing environment makes it favorable for $\mathrm{Fe}$ and $\mathrm{Mn}$ to replace the $\mathrm{Ca}$ and $\mathrm{Mg}$ ions in the dolomite lattice [37]. In contrast to strontium and sodium, the contents of Fe and Mn in diagenetic dolomites are higher than those in early dolomites. The Fe and Mn concentrations in the dolomites of the Leikoupo Formation range from $80 \mu \mathrm{g} / \mathrm{g}$ to $560 \mu \mathrm{g} / \mathrm{g}$ (with an average value of $371 \mu \mathrm{g} / \mathrm{g}$ ) and $10 \mu \mathrm{g} / \mathrm{g}$ to $32 \mu \mathrm{g} / \mathrm{g}$ (with an average value of $24 \mu \mathrm{g} / \mathrm{g}$ ), respectively (Figure $6 \mathrm{~d}$, Table 1). The dolomicrite has the lowest contents of $\mathrm{Fe}$ and $\mathrm{Mn}$. The fabric-retentive dolomite and fabric-destructive dolomite have relatively higher Fe and Mn contents, which are consistent with their bright red luminescence. Some algal framework dolomites have abnormally high Fe content, which may be related to the influence of Fe-rich fluids in an open environment during the early diagenetic stage $[30,38]$.

\section{Discussion}

\subsection{Dolomitization Models}

Petrologic and geochemical data reveal that the Leikoupo Formation carbonates have undergone Sabkha model, seepage-reflux model, and burial model processes and experienced multiple dolomitization processes during their deposition and burial stages $[16,20]$. The schematic model for the dolomitization of the Leikoupo Formation in the study area is shown in Figure 7. 

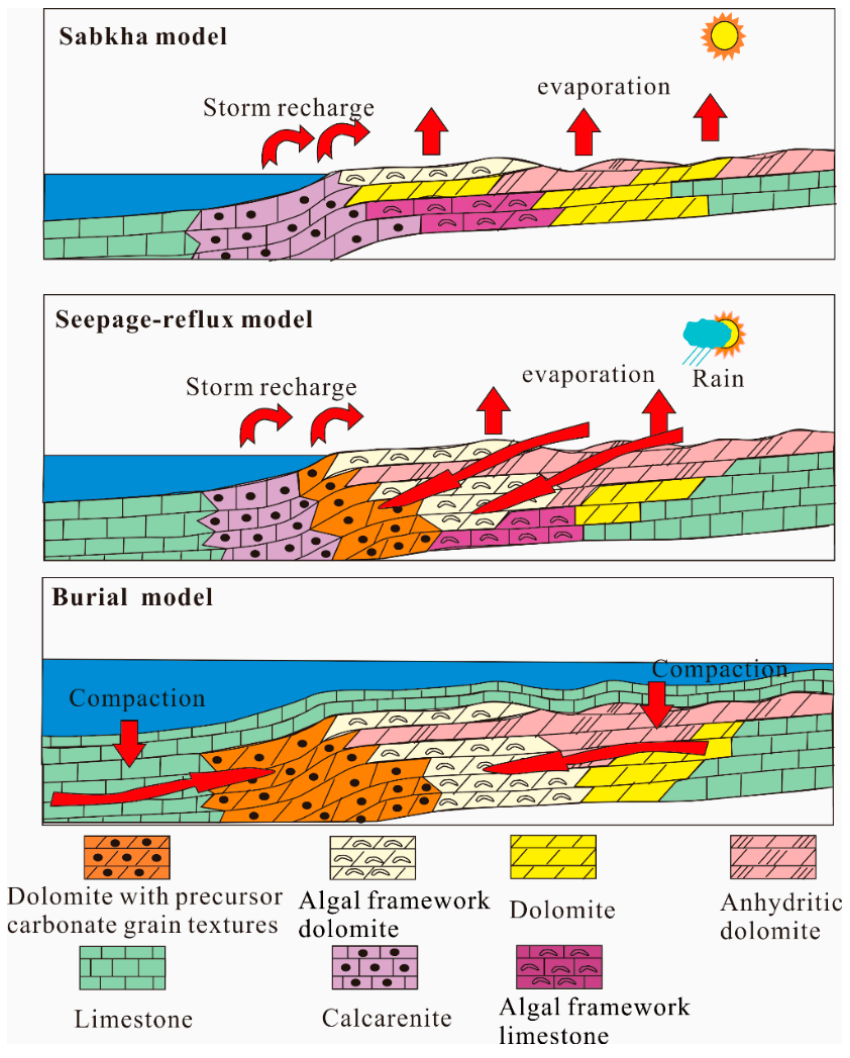

Figure 7. Dolomitization models of the Leikoupo Formation in the Western Sichuan Basin.

\subsubsection{Sabkha Model}

The Leikoupo Formation was deposited in an evaporative intertidal-supratidal flat environment $[16,20]$, and its calculated $Z$ values of ancient salinity are generally higher than 130 , thus reflecting a relatively limited-evaporation background. The dolomicrite records relatively positive $\delta^{18} \mathrm{O}$ values, higher $\mathrm{Mg} / \mathrm{Ca}$ ratios and abnormally high $\mathrm{Sr}$ and $\mathrm{Na}$ contents, indicating that these dolomites formed in a low-temperature, hypersaline environment $[29,39]$. The dolomicrite with lower $\mathrm{Fe}$ and $\mathrm{Mn}$ contents and dull luminescence formed in a near-surface oxidative diagenetic environment $[6,40]$. Detailed petrographic and geochemical analyses indicate that this dolomicrite could be explained by the Sabkha model. This dolomite formed in a high-salinity, shallow burial environment with relatively fast nucleation and crystallization rates, and its dolomitizing fluids may have been recharged by seawater flowing through the shallow subsurface (i.e., driven by tidal pumping or storms) [41]. In the sabkha capillary zone, dolomitization is closely associated with the growth of nodular anhydrite due to an increase in the $\mathrm{Mg}$ :Ca ratio caused by the precipitation of calcium sulphates [42,43].

\subsubsection{Seepage-Reflux Model}

The $\delta^{18} \mathrm{O}$ values in the fabric-retentive dolomite gradually become more depleted compared to the dolomicrite; its formation temperature is higher, and its $\mathrm{Sr}$ and $\mathrm{Na}$ contents are relatively low. The wide range of $\mathrm{Fe}$ and $\mathrm{Mn}$ contents and corresponding bright red luminescence of the fabric-retentive dolomite indicate that dolomitization occurred in the shallow burial stage and that the fluid used for dolomitization was affected by meteoric freshwater $[38,44]$. The fabric-retentive dolomite records the highest ${ }^{87} \mathrm{Sr} /{ }^{86} \mathrm{Sr}$ ratio, which indicates that the influx of radiogenic Sr occurred during diagenesis $[43,45]$. Geochemical analyses indicate that the fabric-retentive dolomite could be explained by the seepage-reflux model during the shallow burial stage and the influence of meteoric water and recrystallization during diagenesis $[44,46]$. In restricted lagoons or platforms, seawater may 
become concentrated due to evaporation (particularly in arid climates), forming dense dolomitizing brines that infiltrate downwards through the underlying sediments [30,43]. The original structures of the algal framework and carbonate grain textures retain their good initial porosity with shallow burial. The abundance of evaporitic minerals in these dolomites, such as anhydrite, supports the movement of saline brines through these strata [47].

\subsubsection{Burial Model}

The fabric-destructive dolomite has the highest $\mathrm{MgO}$ and $\mathrm{CaO}$ contents; the negative linear correlation between $\mathrm{CaO}$ and $\mathrm{MgO}$ reflects the metasomatism of the dolomite after the deposition and burial stage [29,39]. This dolomite records the lowest $\mathrm{Sr}$ and Na contents, higher Fe and Mn contents, and the lowest ${ }^{87} \mathrm{Sr} /{ }^{86} \mathrm{Sr}$ values, which indicate that the diagenetic fluids are likely mainly related to trapped seawater and diagenetic alteration in a closed environment $[6,48,49]$. The depleted $\delta^{18} \mathrm{O}$ values (down to $-6.79 \%$ ) yield thermometry results indicating that the dolomite precipitated at relatively higher temperatures $\left(75\right.$ to $80^{\circ} \mathrm{C}$ ) [48]. Geochemical analyses indicate that the fabric-destructive dolomite could be explained by the burial model. The hypersaline seawater preserved in these pores was released under the compaction of the overlying strata and migrated along the pores and diagenetic fractures; the early dolomicrite and fabric-retentive dolomite underwent recrystallization to form the fabric-destructive dolomite.

\subsection{Dissolution Models}

The observations of cores and thin sections indicate that the dissolution of dolomite in the Leikoupo Formation is very well developed. Based on the characteristics of filling minerals in the dissolved pores and geochemical evidence, the carbonate rocks in the Leikoupo Formation have experienced contemporaneous and burial dissolution (Figure 8).

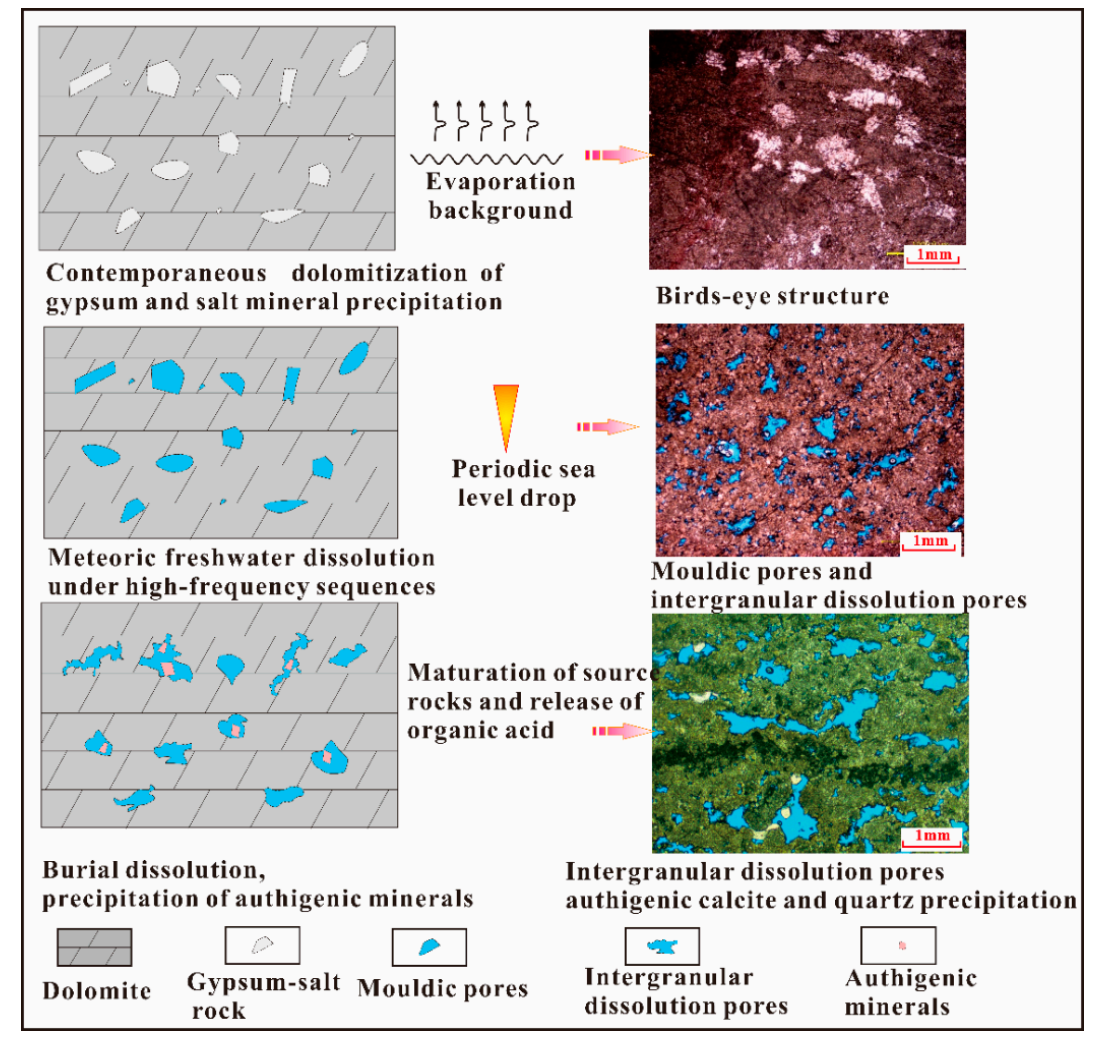

Figure 8. Dissolution models of the Leikoupo Formation dolomite in the Western Sichuan Basin. 


\subsubsection{Contemporaneous Dissolution}

During the sedimentary period of the Leikoupo Formation, the strongly evaporating tidal flat environment formed a large amount of gypsum and salt. Although these minerals occupy many of the early primary pores, they also provide soluble substances for subsequent dissolution. The fluctuations in sea level controlled by multiple high-frequency sequences can cause the entire evaporating platform to be exposed and modified by meteoric freshwater [4,50]. The wide variation in $\delta^{13} \mathrm{C}$ values, wide range of Fe and Mn contents (Figure 6), bright red luminescence, and the highest ${ }^{87} \mathrm{Sr} /{ }^{86} \mathrm{Sr}$ ratios of the fabric-retentive dolomite indicate that this dolomite is likely closely related to meteoric water $[38,48,51]$. A large number of algal framework pores, moldic pores, and intergranular dissolution pores are visible in thin sections (Figure $2 b, c, e)$. These pores often have clean edges, and a small amount of gypsum dissolution residue is visible (Figure 2f). The high-quality reservoir exhibits a multi-stage superimposed and horizontally layered distribution, with most layers ranging in thickness from $5 \mathrm{~m}$ to $10 \mathrm{~m}$; the thickness is mainly related to the time of exposure under multiple high-frequency sequences.

\subsubsection{Burial Dissolution}

After entering the burial stage, the source rocks gradually enter the mature stage; organic acid fluids occur along the structural fractures and stylolite in the pre-pore system, preferentially dissolving authigenic minerals (i.e., residual gypsum, calcite). This process is also sometimes expressed as the dissolution of dolomite wall rocks. Residual bitumen can be seen in intercrystalline pores and large dissolved pores (Figure 2c,e). Fillings of parry calcite can be seen in the partial dissolution pores, with lower $\delta^{18} \mathrm{C}$ values indicating the presence of organic acids [51]. The most negative observed $\delta^{18} \mathrm{O}$ values indicate that the calcite formed at relatively higher temperatures during further burial.

\section{Conclusions}

Petrographic observations indicate there are three main types of dolomite fabric in the Leikoupo Formation, i.e., dolomicrite, fabric-retentive dolomite, and fabric-destructive dolomite. The most important pore types are the algal framework pores, intergranular dissolved pores, and moldic pores, which account for $70 \%$ of all pores.

Geochemical analyses indicate that the $\delta^{18} \mathrm{O}$ values of the dolomicrite are relatively positive; these rocks exhibit higher $\mathrm{Mg} / \mathrm{Ca}$ ratios, abnormally higher $\mathrm{Sr}$ and $\mathrm{Na}$ contents, and dull luminescence. The $\delta^{18} \mathrm{O}$ values of the fabric-retentive dolomite gradually become more depleted compared to the dolomicrite, with a wider range of Fe and Mn contents, bright luminescence, and the highest ${ }^{87} \mathrm{Sr} /{ }^{86} \mathrm{Sr}$ ratios. The fabric-destructive dolomite has lower $\mathrm{Mg} / \mathrm{Ca}$ ratios, the lowest $\mathrm{Sr}$ and $\mathrm{Na}$ contents, higher Fe and Mn contents, and the lowest ${ }^{87} \mathrm{Sr} /{ }^{86} \mathrm{Sr}$ values, as well as extremely depleted $\delta^{18} \mathrm{O}$ values reflecting higher precipitation temperatures.

The dolomicrite precipitated from hypersaline seawater near the surface following the Sabkha model. The fabric-retentive dolomite could be explained by the seepage-reflux model as having formed in a shallow-burial environment before being altered by meteoric water. The fabric-destructive dolomite can be explained by the burial model.

This formation has undergone multistage dissolution. The first phase of penecontemporaneous meteoric dissolution occurred under high-frequency sequences. This phase mainly comprised the dissolution of gypsum, rock salt and calcite, which form the algal framework pores, moldic pores, and intergranular dissolution pores. The second phase mainly involved organic acid dissolution during the burial period, which mainly resulted in the redistribution of the early dissolution pores.

Author Contributions: Conceptualization: Z.L.; formal analysis: Y.W.; data curation: Y.W.; writing—original draft preparation: S.Z.; and writing-review and editing: S.Z., S.L., Z.L. All authors read and approved the manuscript.

Funding: This research was supported by the Southeast Branch Company of SINOPEC (34450000-15-ZC0607-0014). 
Acknowledgments: We thank the anonymous reviewers for their valuable suggestions and kind help in improving the quality of the manuscript, and the Southeast Branch Company of SINOPEC for sample collection and technical support.

Conflicts of Interest: The authors declare no conflict of interest.

\section{References}

1. Cao, B.F.; Bai, G.P.; Wang, Y.F. More attention recommended for global deep reservoirs. Oil Gas J. 2013, 111, 78-85.

2. Ma, Y.S.; Cai, X.Y.; Zhao, P.R. The research status and advances in porosity evolution and diagenesis of deep carbonate reservoir. Earth Sci. Front. 2011, 18, 181-192. (In Chinese with English Abstract).

3. Zhao, W.Z.; Wang, Z.C.; Zhang, S.C.; Wang, H.J. Analysis on forming conditions of deep marine reservoirs and their concentration belts in superimposed basins in China. Chin. Sci. Bull. 2007, 52, 12-27. [CrossRef]

4. Moore, C.H. Carbonate Reservoirs: Porosity, Evolution and Diagenesis in a Sequence Stratigraphic Framework; Elsevier Science: Amsterdam, The Netherlands, 2001.

5. Lucia, F.J. Carbonate Reservoir Characterization; Springer: Berlin/Heidelberg, Springer, 2007.

6. Tucker, M.E.; Wright, V.P. Carbonate Sedimentology; Blackwell Scientific Publications: Oxford, UK, 1990.

7. Scholle, P.A.; Ulmer-Scholle, D.S. A color guide to the petrography of carbonate rocks: Grains, textures, porosity, diagenesis. AAPG Mem. 2003, 77, 1-486.

8. Aqrawi, A.M.; Keramati, M.; Ehrenberg, S.N.; Pickard, N.; Moallemi, A.; Svånå, T.; Darke, G.; Dickson, J.A.D.; Oxtoby, N.H. The origin of dolomite in the Asmari Formation (Oligocene-lower Miocene), Dezful Embayment, SW Iran. J. Pet. Geol. 2006, 29, 381-402. [CrossRef]

9. Purser, B.; Tucker, M.; Zenger, D. Dolomites: A Volume in Honour of Dolomieu; Blackwell Scientific Publications: Oxford, UK, 1994.

10. Heydari, E.; Moore, C.H. Burial diagensis and thermochemical sulfate reduction, Smackover Formation, southeastern Mississippi salt basin. Geology 1989, 17, 1080-1084. [CrossRef]

11. Huang, S.J.; Gong, Y.C.; Huang, K.K.; Tong, H.P. The influence of burial history on Carbonate Dissolution and Precipitation-A case study from Feixianguan Formation of Triassic, NE Sichuan and Ordovician Carbonate of Northern Tarim Basin. Adv. Earth Sci. 2010, 25, 381-390. (In Chinese with English Abstract).

12. Machel, H.G. Bacterial and thermochemical sulfate reduction in diagenetic settings-old and new insights. Sediment. Geol. 2001, 140, 143-175. [CrossRef]

13. Amel, H.; Jafarian, A.; Husinec, A.; Koeshidayatullah, A.; Swennen, R. Microfacies, depositional environment and diagenetic evolution controls on the reservoir quality of the Permian Upper Dalan Formation, Kish Gas Field, Zagros Basin. Mar. Pet. Geol. 2015, 67, 57-71. [CrossRef]

14. Ehrenberg, S.N.; Eberli, G.P.; Keramati, M.; Moallemi, S.A. Porosity-permeability relationships in interlayered limestone-dolostone reservoirs. AAPG Bull. 2006, 90, 91-144. [CrossRef]

15. Li, H.T.; Hu, X.Y.; Shi, Y.Q.; Xiao, K.H.; Jia, Y.W.; Wei, X.P.; Feng, Q. Sequence division and controlling factors of reservoir development of the 4th Member of Leikoupo Formation in foreland of Longmen Mountains in the Western Sichuan Depression, Sichuan Basin. Oil Gas Geol. 2017, 38, 753-763. (In Chinese with English Abstract).

16. Li, S.B.; Xu, G.M.; Song, X.B. Forming conditions of Pengzhou large gas field of Leikoupo Formation in Longmenshan piedmont tectonic belt, western Sichuan Basin. China Pet. Explor. 2016, 3, 74-82. (In Chinese with English Abstract).

17. Wu, S.X.; Li, H.T.; Long, S.X.; Liu, Z.L.; Wang, C.L.; Zhang, J.T. A study on characteristics and diagenesis of carbonate reservoirs in the Middle Triassic Leikoupo Formation in western Sichuan Depression. Oil Gas Geol. 2011, 32, 542-550. (In Chinese with English Abstract).

18. Wu, X.; Chen, Y.; Liu, G.; Zeng, H.; Wang, Y.; Hu, Y.; Liu, W. Geochemical characteristics and origin of natural gas reservoir the natural gas reservoir in the 4th Member of the Middle Triassic Leikoupo Formation in the Western Sichuan Depression, Sichuan Basin, China. J. Nat. Gas Geosci. 2017, 2, 99-108. [CrossRef]

19. Ding, X.; Wang, B.; Wang, X.; Liu, H.; Zeng, D.; Feng, M. The three different types of paleokarstification and reservoir distribution of Leikoupo Formation, Middle Triassic in the Northern Sichuan Basin, China. Carbonates Evaporites 2017, 5, 1-12. [CrossRef] 
20. Li, L.; Tan, X.; Cao, J.; Zou, C.; Ding, X.; Yang, G.; Ying, D. Origins of evaporites in the Middle Triassic Leikoupo Formation of the Sichuan Basin, southwest China and their geological implications. Carbonates Evaporites 2014, 29, 55-63. [CrossRef]

21. Savard, M.M.; Veizer, J.; Hinton, R. Cathodoluminescene at low Fe and Mn concentrations: A SIMS study of zones in natural calcites. J. Sediment. Res. 1995, 65, 208-213. [CrossRef]

22. Machel, H.G. Concepts and models of dolomitization: A critical reappraisal. Geol. Soc. Lond. Spec. Publ. 2004, 235, 7-63. [CrossRef]

23. Montanez, I.P.; Read, J.F. Fluid-rock interaction history during stabilization of early dolomites, Upper Knox Group (Lower Ordovician), US Appalachians. J. Sediment. Res. 1992, 62, 753-778.

24. El-Shazly, S.H. Stable isotope of some selected Egyptian pectinids and their paleoenvironmental implications. J. Afr. Earth Sci. 2011, 59, 283-294. [CrossRef]

25. Keith, M.L.; Weber, J.N. Carbon and oxygen isotopic composition of selected limestones and fossils. Geochim. Cosmochim. Acta 1964, 28, 1787-1816. [CrossRef]

26. Wang, C.; Deng, J.; Zhang, S.; Zhang, D.; Yang, L. Carbon and oxygen isotope relations and its significance. Geochim. Cosmochim. Acta. 2009, 73, A1407.

27. Fritz, P.; Smith, D.G.W. The isotopic composition of secondary dolomite. Geochim. Cosmochim. Acta 1970, 34, 1161-1173. [CrossRef]

28. Dickson, J.A.D.; Coleman, M.L. Changes in carbon and oxygen isotope composition during limestone diagenesis. Sedimentology 1980, 27, 107-118. [CrossRef]

29. Shen, A.; Zheng, J.; Chen, Y.; Xinfeng, N.I.; Huang, L. Characteristics, origin and distribution of dolomite reservoirs in lower-middle cambrian, tarim basin, NW China. Pet. Explor. Dev. 2016, 43, 375-385. [CrossRef]

30. Ren, Y.; Zhong, D.; Gao, C.; Sun, H.; Peng, H.; Zheng, X.; Qiu, C. Origin of dolomite of the lower Cambrian Longwangmiao Formation, eastern Sichuan Basin, China. Carbonates Evaporites 2017, 1, 1-20. [CrossRef]

31. Ye, Q.; Mazzullo, S.J. Dolomitization of lower permian platform facies, Wichita Formation, north platform, Midland basin, Texas. Carbonates Evaporites 1993, 8, 55-70. [CrossRef]

32. Warren, J. Dolomite: Occurrence, evolution and economically important associations. Earth-Sci. Rev. 2000, 52, 1-81. [CrossRef]

33. Baker, P.A.; Burns, S.J. Occurrence and formation of dolomite in organic rich continental margin sediments. AAPG Bull. 1985, 9, 1917-1930.

34. Qing, H.; Mountjoy, E.W. Multistage dolomitization in rainbow buildups, middle devonian keg river formation, Alberta, Canada. J. Sediment. Res. 1989, 59, 114-126.

35. Modarres, M.H.; Adabi, M.H.; Fayazi, F.; Ghobishavi, A.; Moradpour, M. Petrography and geochemical composition of the middle Eocene, the Shahabazan Formation at Kialu Section, Zagros Basin, Southwestern Iran. Carbonates Evaporites 2018, 1, 1-13. [CrossRef]

36. Veizer, J.; Lemieux, J.; Jones, B.; Gibling, M.R.; Savelle, J. Paleosalinity and dolomitization of a lower paleozoic carbonate sequen. Can. J. Earth Sci. 1978, 15, 1448-1461. [CrossRef]

37. Allan, J.R.; Wiggins, W.D. Dolomite reservoirs: Geochemical techniques for evaluating origin and distribution. J. Pet. Sci. Eng. 1993, 14, 262-263.

38. Budd, D.A. Cenozoic dolomites of carbonate islands: Their attributes and origin. Earth-Sci. Rev. 1997, 42, 1-47. [CrossRef]

39. Lu, X.; Shi, J.; Zhang, S.; Zou, N.; Sun, G.; Zhang, S. The origin and formation model of Permian dolostones on the northwestern margin of Junggar Basin, China. J. Asian Earth Sci. 2015, 105, 456-467. [CrossRef]

40. Azmy, K.; Veizer, J.; Misi, A.; Oliveira, T.F.D.; Sanches, A.L.; Dardenne, M.A. Dolomitization and isotope stratigraphy of the Vazante Formation, Sao Francisco Basin, Brazil. Precambr. Res. 2001, 112, 303-329. [CrossRef]

41. Chan, M.Y.; Yong, I.L. Origin and modification of early dolomites in cyclic shallow platform carbonates, Yeongheung Formation (middle Ordovician), Korea. Sediment. Geol. 1998, 118, 141-157.

42. Alsharhan, A.S.; Whittle, G.L. Sedimentary-diagenetic interpretation and reservoir characteristics of the Middle Jurassic (Araej Formation) in the southern Arabian Gulf. Mar. Pet. Geol. 1995, 12, 615-628. [CrossRef]

43. Rahimpour-Bonab, H.; Esrafili-Dizaji, B.; Tavakoli, V. Dolomitization and anhydrite precipitation in Permo-Triassic carbonates at the south pars gas field, offshore Iran: Controls on reservoir quality. J. Pet. Geol. 2010, 33, 43-66. [CrossRef] 
44. Huang, S.J.; Huang, K.K.; Lu, J.; Lan, Y.F. The relationship between dolomite textures and their formation temperature: A case study from the Permian Triassic of the Sichuan Basin and the lower Paleozoic of the Tarim Basin. Pet. Sci. 2014, 11, 39-51. [CrossRef]

45. Moore, C.H.; Chowdhury, A. Upper Jurassic Smackover Platform Dolomitization, Northwestern Gulf of Mexico: A Tale of Two Waters. In Sedimentology and Geochemistry of Dolostones; Shukla, V., Baker, P.A., Eds.; Society of Economic Paleontologists and Mineralogists (SEMP): Tulsa, OK, USA, 1988; pp. 175-189.

46. Zhang, L.; Jiao, Y.; Rong, H.; Li, R.; Wang, R. Origins and Geochemistry of Oolitic Dolomite of the Feixianguan Formation from the Yudongzi Outcrop, Northwest Sichuan Basin, China. Minerals 2017, 7, 120. [CrossRef]

47. Mansour, A.S.; Abd-Ellatif, M.T. Dolomitization of the Miocene carbonates in Gebel Abu Shaar El Qiblie and Salum area, Egypt: A petrographical and geochemical comparative study. Carbonates Evaporites 2013, 28, 347-363. [CrossRef]

48. Armstrong-Altrin, J.S.; Verma, S.P.; Lee, Y.I.; Worden, R.H. Carbon, oxygen, and strontium isotope geochemistry of carbonate rocks of the upper Miocene Kudankulam Formation, southern India: Implications for paleoenvironment and diagenesis. Chem. Erde Geochem. 2009, 69, 45-60. [CrossRef]

49. Rahimi, A.; Adabi, M.H.; Aghanabati, A.; Majidifard, M.R.; Jamali, A.M. Dolomitization Mechanism Based on Petrography and Geochemistry in the Shotori Formation (Middle Triassic), Central Iran. Open J. Geol. 2016, 6, 1149-1168. [CrossRef]

50. Zhao, W.Z.; Luo, P.; Chen, G.; Cao, H.; Zhang, B. Origin and reservoir rock characteristics of dolostones in the early triassic Feixianguan formation, NE Sichuan basin, China: Significance for future gas exploration. J. Pet. Geol. 2010, 28, 83-100. [CrossRef]

51. Khalaf, F.I.; Abdullah, F.A.; Gharib, I.M. Petrography, diagenesis and isotope geochemistry of dolostones and dolocretes in the Eocene Dammam Formation, Kuwait, Arabian Gulf. Carbonates Evaporites 2017, 1-3, 1-19. [CrossRef]

(C) 2018 by the authors. Licensee MDPI, Basel, Switzerland. This article is an open access article distributed under the terms and conditions of the Creative Commons Attribution (CC BY) license (http:/ / creativecommons.org/licenses/by/4.0/). 